PP Periodica Polytechnica
Architecture

47(1), pp. 49-55, 2016

DOI: 10.3311/PPar.9557

Creative Commons Attribution (i)

RESEARCH ARTICLE

\section{Alteration in the Awareness of Estonian City Space from Independence to Stalinism}

\author{
Siim Sultson ${ }^{1 *}$
}

Received 03 June 2016; accepted 18 September 2016

\begin{abstract}
The presented research focuses on the alteration of Estonian city space awareness within the period of the mid-1940s and 1950s. Soviet occupation changed Estonian city space as the materialisation of ideology. Paradoxically, regardless of the war's destruction and occupying Soviet regime, Stalinist town planning principles generally matched with Estonian architects' city visions. Some existing towns (for instance Tallinn, Pärnu, Narva) gained new centres due to the damage from the war and for ideological reasons. Meanwhile, new industrial towns, as examples of Stalinist utopia, were built in EastEstonia during 1940s-1950s by the Soviet regime to exploit local mineral resources. While the Tallinn, Pärnu, Tartu new Stalinist centres were designed by local architects, the new industrial towns represented so-called imperial city space principles elaborated under the guidance of the Leningrad construction departments. Was there any difference between the pre-war independence period city space and the Stalinist period city space? Where lies the alteration of Estonian city space awareness from independence to Stalinism?
\end{abstract}

\section{Keywords}

city space, architecture, Stalinism, ideology

\section{Introduction}

Similarly, to interwar Italy and Germany, Soviet Stalinist town planning seemed anachronistic but paradoxically embodying harmony, functionality and effectiveness. While strict and radiant urban gridlines most strongly appeared in the states mentioned above, the new trend was quite similar both in authoritarian and democratic countries. Strictly organised, axial town planning, well known since Roman times via Renaissance and Classicism, in the 20th century is a rather functional approach to organising a town gridline. It was supposed to make the state more effective and enterprising. According to City Beautiful movement, a stately urban ensemble has always been supposed to embody dignity, power, a harmonious society, and to monumentalize the latter one. On the one hand, the dictatorial state tries to justify its ideology via traditional urban ensemble, whilst on the other, to see the same ensemble as trustworthy to crystallise the state's ideology. For instance, both Nazi Germany and Soviet Stalinist architecture and town planning are rather similar, with the differences existing mostly in details and sources (Kruft, 1994, p. 423).

After World War II, Estonian local architectural organisations (The Union of Estonian Architects, etc) were unified with the Soviet organisations. Estonian city space was compelled to follow the Soviet doctrine by concept, forms, and building materials. The most radical solution meant the replacement of the city and its inhabitants. The new principles both changed Estonian city space experience-based knowledge, and at the same time, provided an opportunity for architects to carry out some of their oversized dreams from the pre-war independence period.

\section{Stately façade: inevitable prerequisite for a young country's identity}

In the 1930s, similarly to global tendencies, the Republic of Estonia started to focus its architecture on stately urban ensembles as an architectural element, enabling the young country to develop its stately façade. This tendency increased even as Estonia became more authoritarian.

The young republic was interested in the state's representative façade being incarnated via town planning, and the city space. To tackle the dream, it was intended that the central

\footnotetext{
${ }^{1}$ Department of Architecture and Urban Studies,

Faculty of Civil Engineering,

Tallinn University of Technology,

Ehitajate tee 5, 19086 Tallinn, Estonia

${ }^{*}$ Corresponding author, e-mail: siim.sultson@eek.ee
} 
city spaces of Tallinn, Tartu, Pärnu and other towns would be redesigned. According to President Konstantin Päts's decree of $27^{\text {th }}$ May 1936, all the façades in the Tallinn Liberty Square district could be designed or redesigned only with permission of the president; all buildings nearby Liberty Square due to their representative appearance could be demolished by government order. ("Vabadussõja üleriikliku mälestusmonumendi püstitamise seadus", 1936, p. 1028)

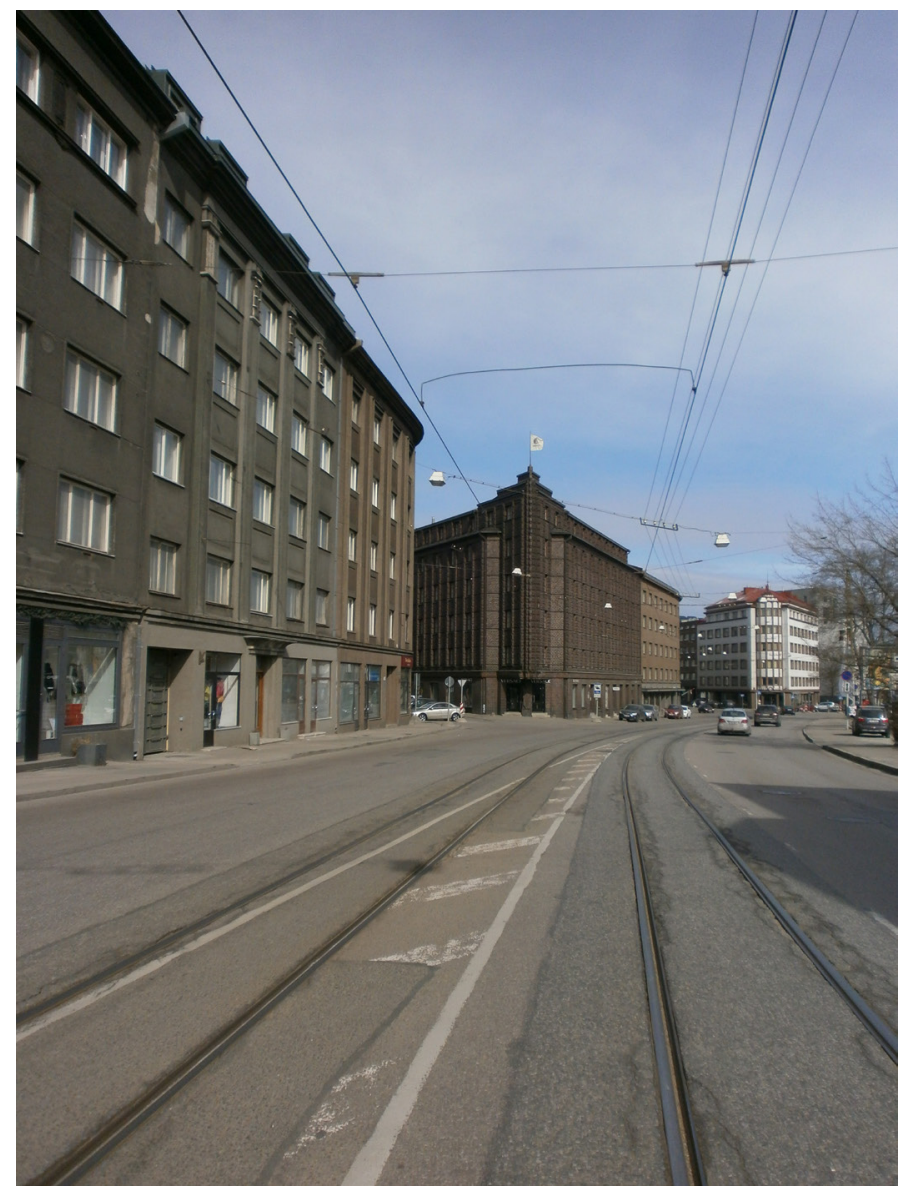

Fig. 1 Pärnu Road apartment buildings nearby Liberty Square in Tallinn from the late 1930s. Photo source: Siim Sultson

Benchmarking independent Estonian 1930s town planning with Soviet period Estonian 1940s-1950s practice, Stalinist principles brought by Soviet occupation were rather similar to local ones differing mainly by quantity and methodology. For example, during the Tallinn Liberty Square city space architectural competition in 1937, one of the proposals (Harald Arman, Salme Vahter-Liiver) suggested doubling the area of the square by demolishing St John's church and a school building nearby. Though the contenders suggested removing the church (Bölau, 1937, p. 86-87), the jury regardless dismissed the Arman's and Vahter-Liiver's proposal as too enormous still decided to purchase the project. (ERA 2218.1.223, 34)
In 1939, the new business and transport centre (H. Arman) was started in the storehouses' area in the suburb on the outskirts of Pärnu. The new centre was supposed to be as large as the old mediaeval town. (ERA 3799.1.33, 3)

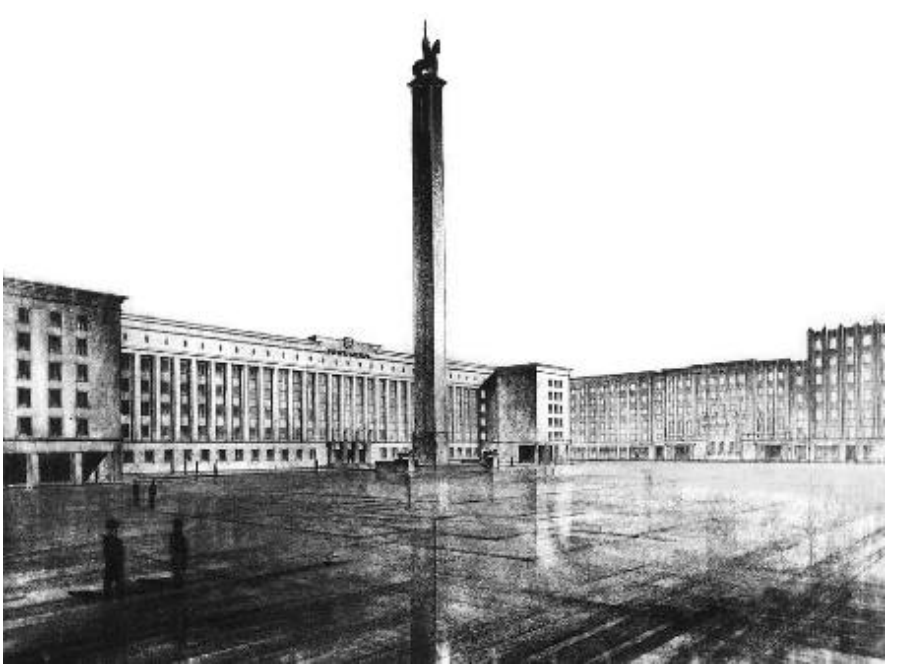

Fig. 2 Winning entry for Liberty Square in Tallinn, 1937, by Alar Kotli Source: EAA.2111.1.15409,5

At the same time, the new institutional ensemble (Harald Sultson) was started in Tartu centre around the Tartu University. According to the project, the monumental ensemble would have replaced some quarters of $18^{\text {th }}-19^{\text {th }}$ century housing. (EAA 2100.6.163)

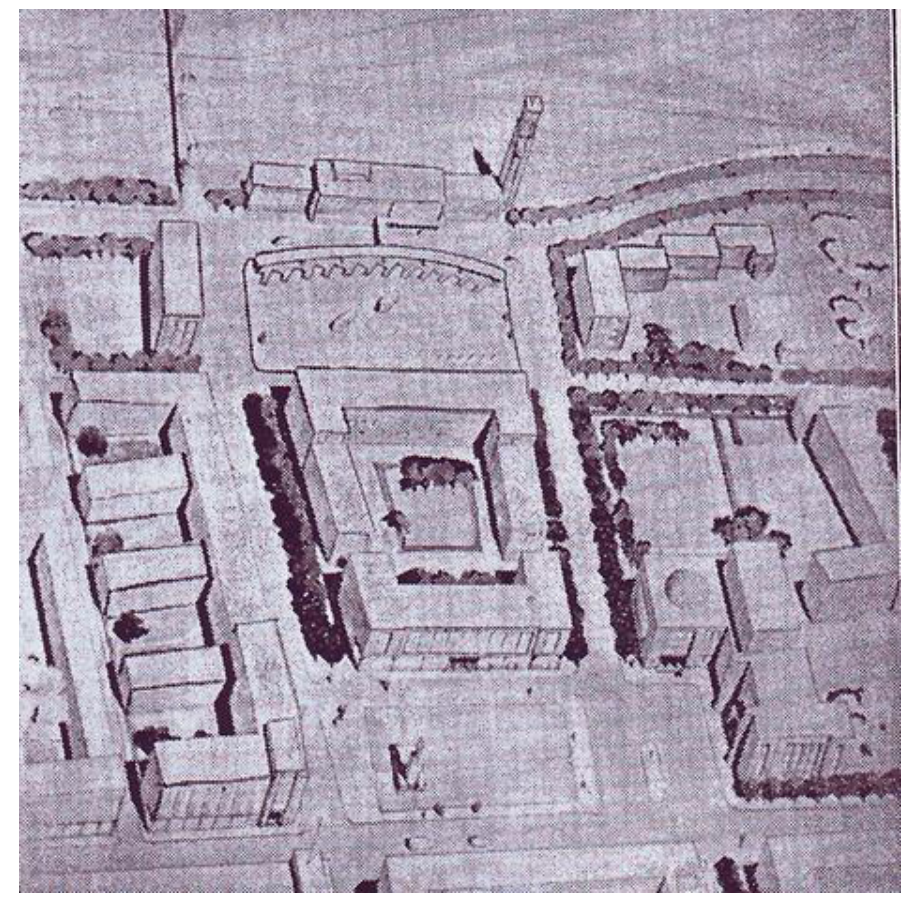

Fig. 3 Winning entry for the new business and transport centre in Pärnu, 1938 by Harald Arman. Source: ERA 3799.1.33,3 


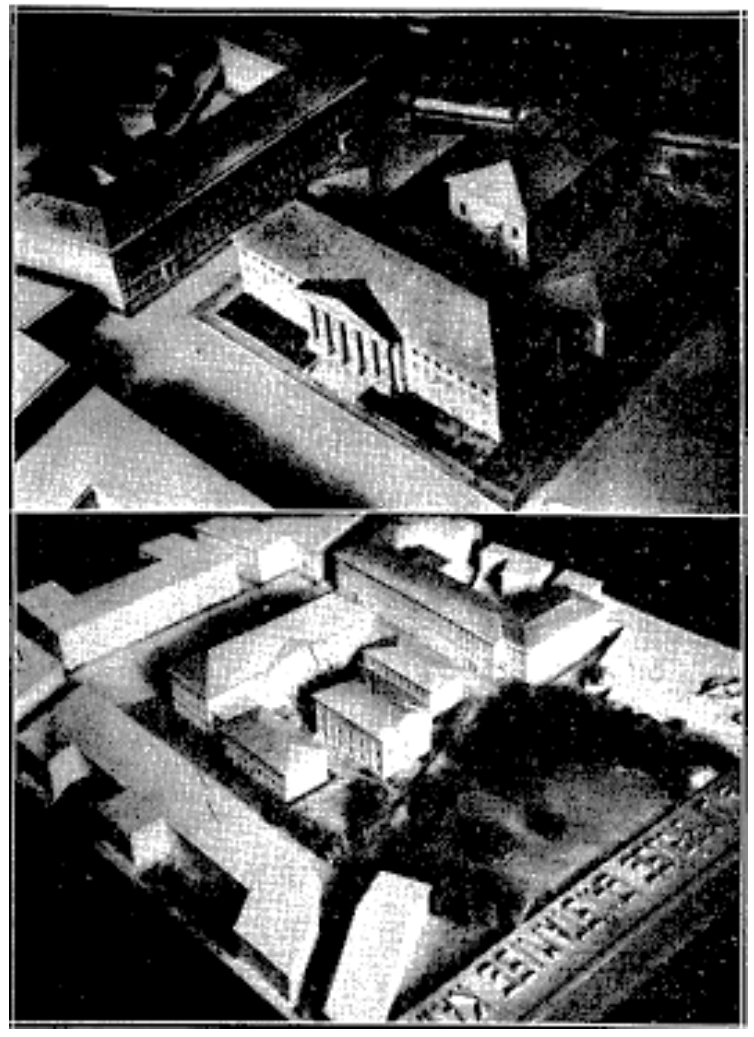

Fig. 4 Design for the new institutional ensemble around Tartu University, 1938 by Harald Sultson. Source: EAA 2100.6.163; Ülikooli ümbruse ..., 1938

Due to Soviet occupation and World War II neither of the plans were finished.

\section{Soviet Stalinist town planning and socialist realism}

On 15th June 1931, the Communist Party of the Soviet Union's Central Committee's Plenum decided that town planning, including both reconstruction and construction, would be realised under the guidance of the state's central plan for the national economy. (Bunin, 1945, pp. 290, 291)

In January 1932, the Soviet People's Commissar of Education Anatoly Lunacharskiy stated that a task of architecture is to integrate functionality and utility in a harmonized way into an ideological idea (Kosenkova, 2009, pp. 19-20). In February 1932, the Soviet Communist Party found a new ideological method - socialist realism.

Partly reflecting Renee' Descartes's rationalist philosophy of method, socialist realism was intended to collect the best from both history and the contemporary. The new method, one of the important cornerstones of Soviet ideology, was supposed to lead society into an ideal future. Socialist realism was not intended to give up the cultural heritage, but to recycle, to synthesise it on behalf of a better tomorrow. Meanwhile, socialist realism handled culture, architecture, and heritage as a storeroom where one may take whatever and whenever one wants. This method was supposed to "embody an absolute apocalyptical future where the difference between past and future abolishes significance." (Groys, 1998a; 1998b, pp. 641-644, 859)
An indication of the state's increasing enterprising role was the decision of the Palace of the Soviets Construction Council made under the guidance of the Chairman of the Council of People's Commissars Vyacheslav Molotov on February 28th, 1932: according to the Palace of the Soviets, prescribed competitions compel all architects to follow requirements of simplicity, unity and elegance in architecture, and to follow the best example of Classicist architecture in one's creation (Capenko, 1952, p. 73). The Moscow Saviour Church was blown up in December 1931 in order to construct the Palace.

Parallel with the redesigning of Moscow's central structure, the first Stately Union Congress of Soviet Architects, held from 16th - 26th June 1937, stated in the resolution that the principle method of Soviet architecture was socialist realism. According to the new method, the Soviet architect was supposed to be able to produce, in the utmost rapid and industrialised way, architecture that was highly qualified both aesthetically and economically. (Capenko, 1952, pp. 74, 75)

As stated by the Soviet architect Ivan Zholtovskiy, architecture in a city space was supposed to be ensemble-like, where every house had to be ruled by the ensemble. That meant a certain hierarchy where every part had to obey the principle of unity. (Zholtovskij, 1940)

This was the way to generate a method for creating an artistic image to educate and re-educate the masses. "A synthesis of the arts - the bringing together of different forms of art under one architectural "roof." (Kodres, 2008, p. 142)

The new method was supposed to be a measure to solve all social problems in a complex way as effectively as possible. For instance, in the Soviet Union the main principle of Soviet town planning was the Stalinist care for people embodied in Moscow "that by its 800th anniversary had gained a new architectural appearance: axial town planning, well-equipped living quarters, parks, bridges and grandiose administrative buildings completed in accordance with the city reconstruction general plan" (Sovetskaja arhitektura za XXX let RSFSR, 1950, pp. 8, 9).

Due to ideological reasons, private property was forbidden in the Soviet Union. Thus, in comparison with other states, it was easier to operate with a town structure, to control society via the urban space. It was especially crucial after World War II - the necessity to restore wrecked towns gave a rare opportunity to celebrate the victory of the regime and its ideology.

\section{Estonian Stalinist stately city space: old dreams, new principles}

\subsection{The liberal Stalinist stately city space}

The Head of the Department of Architecture of the Estonian SSR H. Arman, residing in the USSR, had already started to organise the restoration of Estonian towns in mid1944 (Gorich, 1946, p. 4). During World War II, according to a plenary resolution of the Soviet Architect's Union of the USSR, the Soviet architects were supposed to be ready for the gigantic restoration 
works after the war(Plenum pravlenija Sojuza arhitektrov, 1943). The following instructions given by the Council of People's Commissars of the USSR and the Soviet Communist Party compelled architects to design and restore wrecked towns more grandiose and according to the stately ideology (Iz istorii sovetskoj arhitektury 1941-1945 gg. Dokumenty i materialy. Hronika voennyh let. Arhitekturnaja pechat. 1978, pp. 94-102, 109).

In 1944, the Head of the Stately Committee of Architecture of the USSR Arkadi Mordvinov stated that the Departments of Architecture of the Estonian SSR, the Latvian SSR and Lithuanian SSR needed aid from the Stately Committee of Architecture of the USSR in the field of town planning methodology based on Soviet experience and ideology (Iz istorii sovetskoj arhitektury 1941-1945 gg. 1978, p. 149).

The following year, Mordvinov formulated the principles of the Soviet post-war town planning that were compulsory for all architects. The formulated principles consisted of seven conditions:

- town planning had to be in tight connection with natural environment in order to expose its beauty;

- town plan needed a balanced compositional centre (for instance centre - main street - railway station square);

- monumental public buildings had to be erected at junctions;

- quarters of dwelling houses had to be planned in a complex way and designed in one ensemble;

- all buildings had to be painted only in light colours (dream of positive future);

- rationality and high quality of structures and infrastructures (electricity, water supply etc) were essential;

- thorough quality surveys both in architects' projects and building process was inevitable. (Kosenkova, 2009, p. 42)

Arman gave local architects certain instructions for town planning in the Estonian SSR. The instructions followed the board resolution of the Soviet Architect's Union of the USSR made on $24^{\text {th }}$ October 1946 , and the plenary resolution of the Soviet Architect's Union of the USSR made on $2^{\text {nd }}$ August 1947. (Meigas, 1948, pp. 5, 7; Arman, 1946, pp. 5-8; Tvorcheskie zadachi sovetskih arhitektorov $v$ pjatiletnem plane vosstanovlenija i razvitija narodnogo hozjajstva. Materialy XII plenuma Sojuza sovetskih arhitektorov SSSR, 1948, pp. 49-61)

While some architects (Voldemar Meigas, Otto Keppe) proposed to restore the centre of Tallinn similarly to Stalinist practice in Leningrad (St Petersburg), others used to design rather similarly to the pre-war independence period practice. For instance, architect Ernst Ederberg tried to restore the old Baroque Narva, and architect Endel Arman creted a restoration project for Pärnu. (ERA R-1992.2.33, 88-92; Ederberg, 1948, pp. 60 - 65; Volkov, 1991, p. 192; Parek, 1971, p. 72) Both of the towns were in quite a satisfactory condition after World War II.

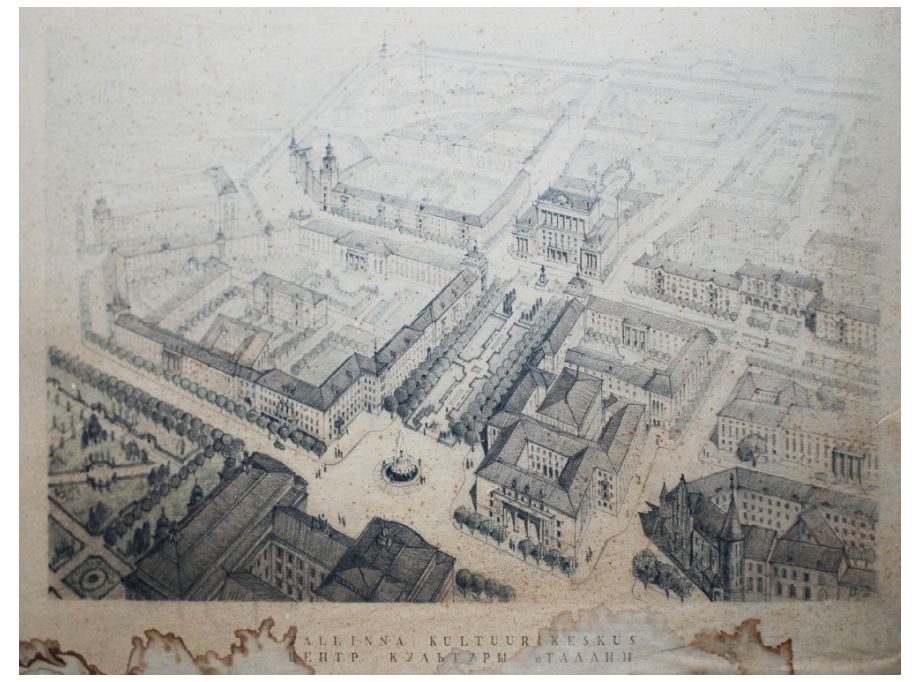

Fig. 5 Entry for the Cultural Centre Square in Tallinn, 1946 by H. Arman. Source: EAM 3.1.31

Architect and the Head of the Department of Architecture of the Estonian SSR, H. Arman balanced between two tendencies. However, Estonian mid 1940s town planning was quite similar to the pre-war independence period disregarding the rest of the Soviet Union architecture. Estonian architects used to design administrative and apartment buildings in a 1930s manner: granite wall coating, modest, scarce ornamentation, only roofs were a slightly more pitched and some Soviet symbols were added. For example, the Tallinn Cultural Centre in front of Estonia theatre and its surroundings was designed under the guidance of H. Arman in the quite same way.

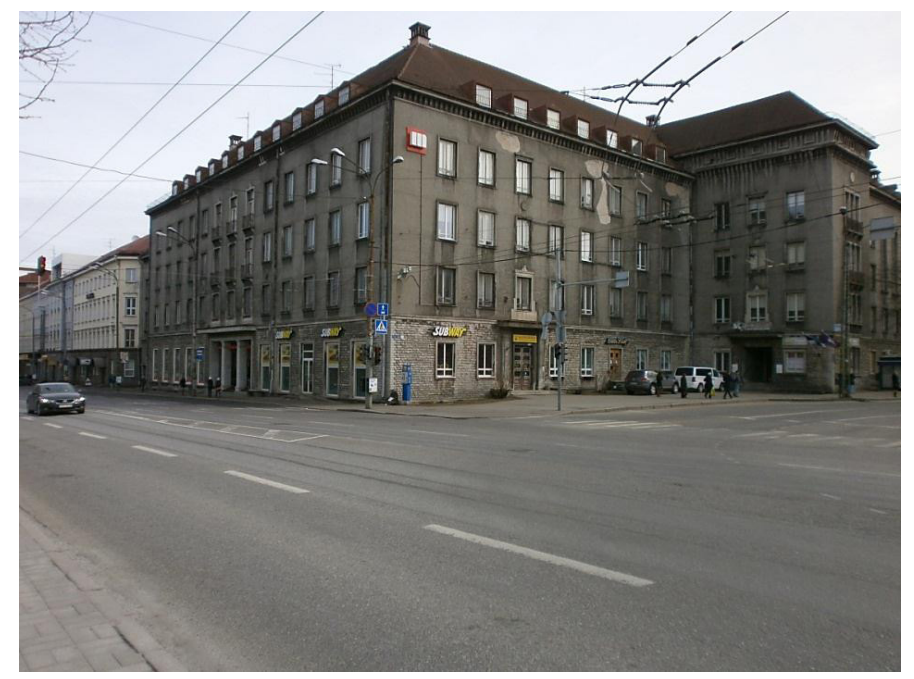

Fig. 6 Estonia Boulevard administrative buildings in Tallinn from the turn of the 1940s and 1950s. City space by H. Arman, the front building is by Enn Kaar. Photo source: Siim Sultson

Meanwhile East Estonian industrial towns Sillamäe, KohtlaJärve, and since the late 1940s, Narva were designed under the guidance of the Leningrad construction departments Lengorstroyproyekt and Lengiproshacht. 
In late 1947, H. Arman declared three principles concerning town centre planning: 1) proper town centre building plan, 2) strict regulation on which buildings were supposed to be erected first, 3) "right" policy of town planning.

According to first principle, H. Arman suggested not to demolish every building, but meanwhile, the future town centre had to have tight connection with the streets (radiant gridline); the main square was supposed to appear dignified from by its measurements and architectonical appearance; administrative buildings, public buildings and cultural objects had to be placed around the central square and to be visible from every radiating street $(\mathrm{H}$. Arman, 1948, pp. 10, 11)

\subsection{The so-called orthodox Stalinist stately city space}

The so-called liberal Stalinist period ended in 1949, with approximately 20,000 inhabitants of Estonia deported to Siberia within one night. Political pressure radiating from Moscow compelled local Estonian architects to design city space more similarly to the capital of USSR (Moscow), Leningrad (St. Petersburg), Stalingrad (Volgograd).

During the $25^{\text {th }}-28^{\text {th }}$ October 1950 , the plenary session of the Soviet Architect's Union of the USSR was dedicated to architects' creative tasks within "the grandiose fifth Stalin fiveyear plan." According to the plenary session resolution, the Soviet architects were supposed to be more active, creative and ideologically aware, dedicated to socialist realism, innovative and use more classicist heritage. (Tvorcheskie zadachi sovetskih arhitektorov, 1951, 5, pp. 7-32, 108-117)

Masterplans of Estonian towns were supposed to be orientated to a prosperous future: more ideologically aware, strictly regulated, and more similar to model cities in the USSR.

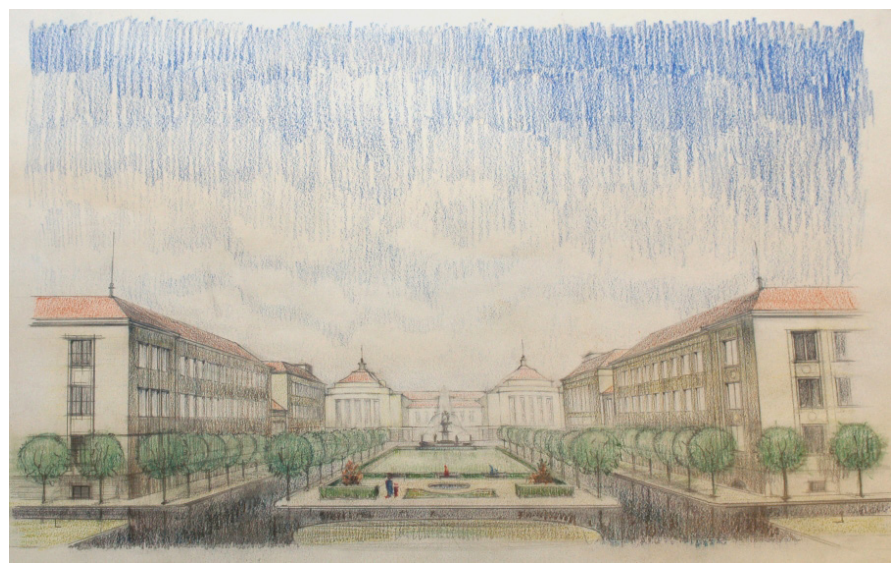

Fig. 7 Entry for the Cultural Centre Square in Tallinn, 1946 by H. Arman. Source: EAM 3.1.13, 32

In 1947 and 1948, E. Arman's restoration project for Pärnu was accepted in the Department of Architecture of the Estonian SSR (ERA R-1992.2.1, 45-48; ERA R-1992.2.33, 74-84). At the same time, the project was passed by the expert opinion of the consultant for the Estonian SSR of the Soviet Academy of Architecture Igor Fomin, to change the project (ERA R-1992.2.33, 139-142). By the end of 1949 and the beginning of 1950, the Department of Architecture of the Estonian SSR merely accepted the consultant's proposals (ERA R-1992.2.33, 104-126). According to the board resolution of the Soviet Architect's Union of the USSR made on $5^{\text {th }}$ June 1952, certain instructions were made in the field of ensemble-like town planning such as for Moscow, Leningrad, Stalingrad (Volgograd), Kiev, Minsk - these were model towns, e.g. set as an example to other towns all over the Soviet Union (Hronika. XIV plenum Pravlenija Sojuza sovetskih arhitektrov, 1952, pp. 31 -33).

In summer 1952, H. Arman himself proposed (with Grigory Schumovskiy and Mart Port) a project for Pärnu. The partly realised town planning project followed Fomin's suggestions. According to the project, many quarters of the burnt but still preserved old town were demolished, the St Nicholas Church (XIV century) in the same condition was blown up. The central square from the 1930s was abandoned, and the town gained an oversized new axial centre instead of the demolished quarters of the old town. Meanwhile, the importance of Pärnu increased as a result of replacing traditional counties with Soviet oblasts by Moscow. (ERA R-1992.2.70, 47; ERA R-1992.2.33, 42-44; Parek, 1971: pp. 42-43; Shumovskij, 1953, p. 3; Härmson, 1983, pp. 35-43)

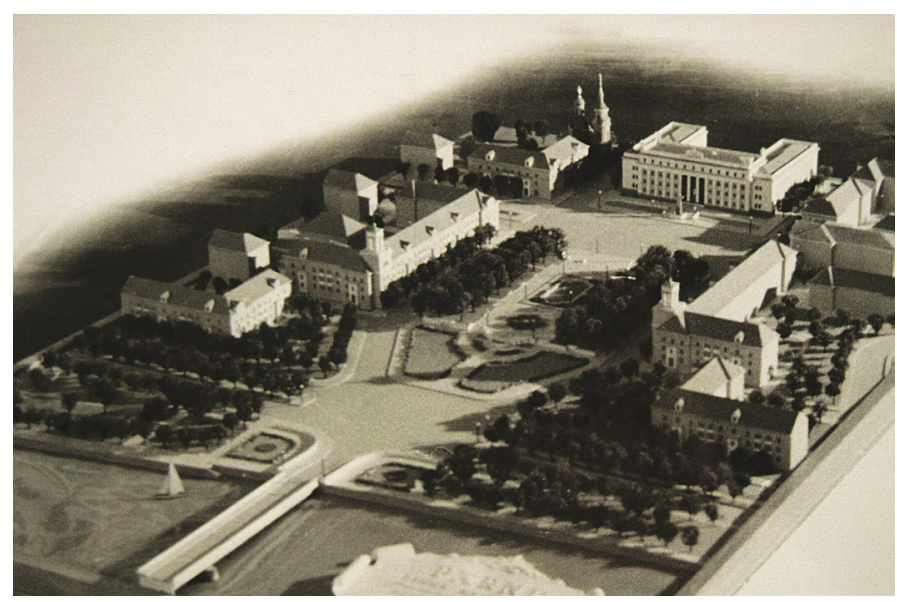

Fig. 8 Pärnu oblast centre by H. Arman, 1952-55. On the site of the demolished Old Town and ruins of the Teutonic Castle. Source: EAM 3.1.323

Since Pärnu was regarded as a future oblast capital, it received a rather grandiose centre plan. While the Soviet architect's handbook (Kratkij spravochnik arhitektora, 1952, pp. 20,21) suggested the design of a 1 hectare central square for the town with the population of 50000 , Pärnu, with the population of 20000 , gained a 2.5-hectare central square. (Ibid.)

Similar anomalies between the size of the population and the area of the town centre could be noticed in the East Estonian industrial towns, Sillamäe, Kohtla-Järve and Narva, which were designed under the guidance of Lengiproshacht and Lengorstroyproyekt residing in Leningrad (St Petersburg).

In comparison to the rest of Estonian towns, Sillamäe and Kohtla-Järve may be regarded as newly designed towns. 
Nevertheless, both of them had small and widely dispersed settlements before the Soviet period. From the 1940s - 1950s, Sillamäe and Kohtla-Järve were designed to be new industrial towns. Unlike the rest of Estonian towns, inhabitants of Sillamäe and Kohtla-Järve were, similarly to Narva, deported from the greater Soviet Union.

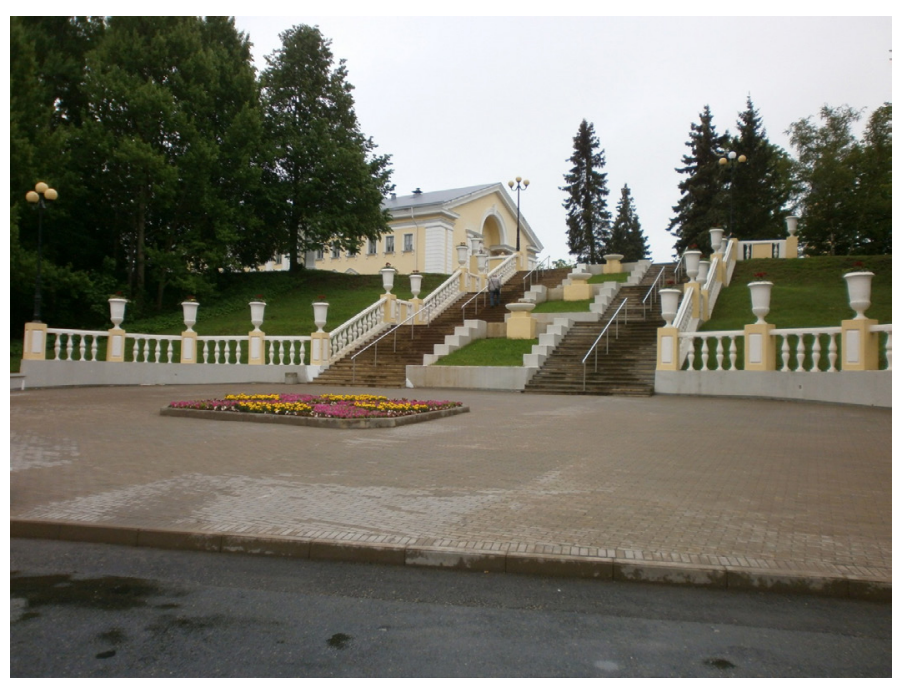

Fig. 9 Stalinist centre of Sillamäe, the early 1950s by Lengiproshacht. Photo source: Siim Sultson.

While Kohtla-Järve was considered an oil-shale mining and processing complex, Sillamäe was a classified town due to the processing of uranium oxides. By the 1950s, both towns, with populations of 10000 , had practically as large representative centres as that seen Pärnu. The representative centre of Sillamäe consists of three main streets crossing a central square and recreational area; the streets are situated on two coastal levels, while the crossing and sea-orientated recreational area connect the levels with a staircase (à la Stalingrad) (ERA.R-1992.2.12).

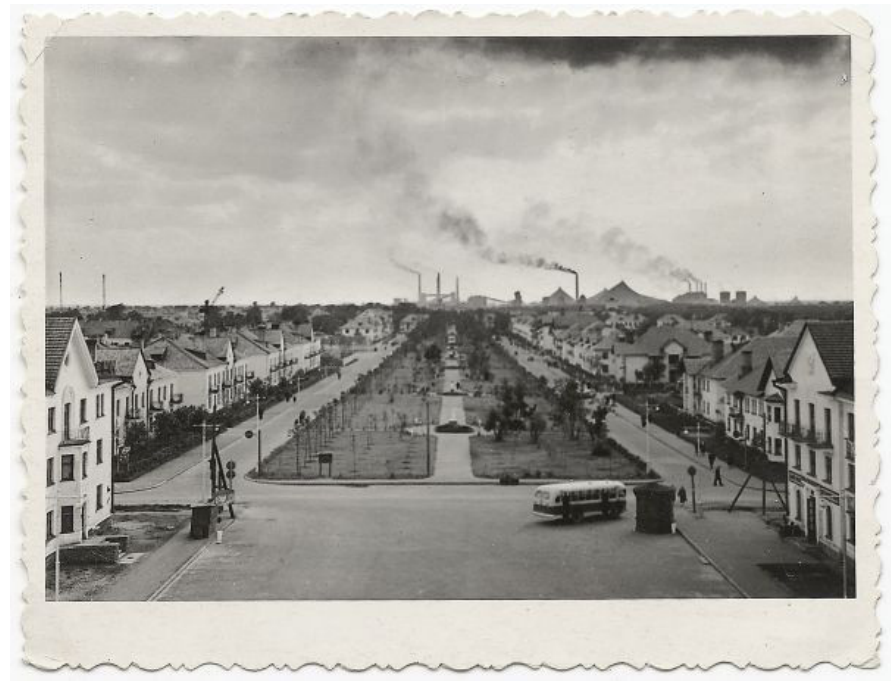

Fig. 10 Stalinist centre of Kohtla-Järve early 1950s, by Lengorstroyproyekt. Photo taken in the 1950s. Source: a postcard
In Kohtla-Järve, the central boulevard that (50 meters wide) connects the house of culture and the central cinema, is crossed by an axis of a local government complex (ERA.R-1992.2.57; ERA.R-1992.2.41).

East Estonian industrial towns were planned mostly by nonlocal architects (especially Sillamäe), for instance, the Stalinist central grid line of Kohtla-Järve has much in common with the Stalinist central gridlines of Tallinn and Pärnu.

These East Estonian industrial towns (Sillamäe, Kohtla-Järve, Narva) received axially arranged representative, sometimes enormous, but generally well balanced and functional plans.

Although Kohtla-Järve and Sillamäe can be regarded as new towns, established during Stalin era, the same attempts (to establish something new) may also be seen both in Tallinn and Pärnu (memory shift, restart).

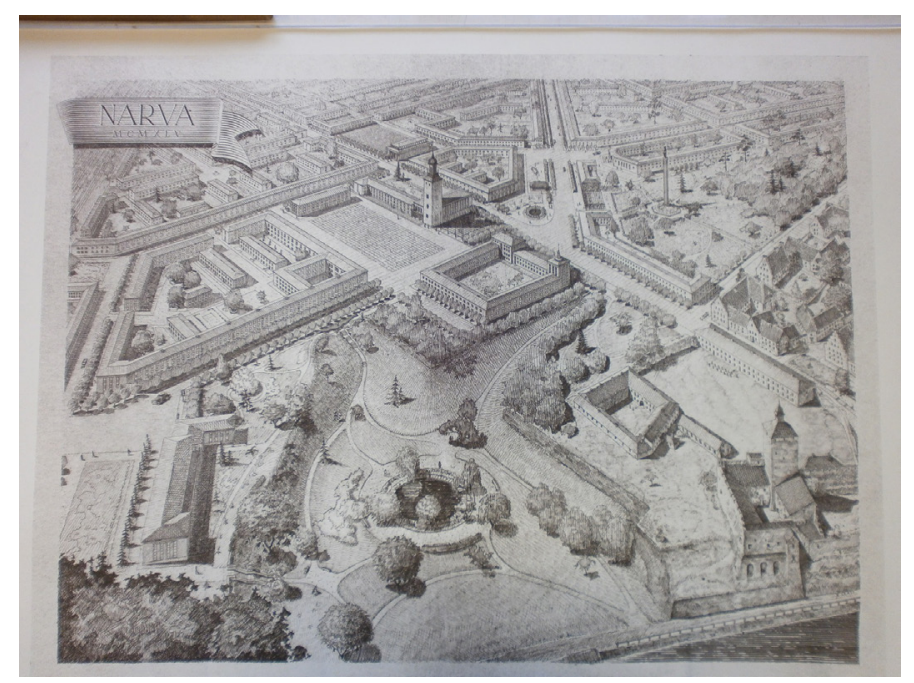

Fig. 11 New Narva plan by by Ernst Ederberg. 1945. Source: EAM 16.1.96

The most drastic restart took place in Narva. While in the 1940s, Ederberg and Anton Soans made a proposal to restore the old Baroque town (Ederberg 1946, pp. 60-65), after the 1949 deportations and the end of so-called liberal Stalinism, the fairly well-preserved ruins were almost completely demolished and replaced with new gridlines and houses.

\section{Conclusions}

Two and a half years after Stalin's death (1953), Stalinist architectural doctrine was ended with the November 1955 resolution of the Communist Party of Soviet Union Central Committee concerning ending of exaggerations in architecture (Ob ustranenii izlishestv v proektirovanii $i$ stroitel'stve. Postanovlenie Central'nogo Komiteta KPSS i Soveta Ministrov SSSR 4 nojabrja 1955 goda, 1955, pp. 8, 11, 13, 15).

It is paradoxical that the Stalinist stately urban ensembles in Estonia provided an opportunity for architects to carry out some of their architectural ideas from the period of independence that had remained on paper. Compared to small independent Estonia, the Soviet Union, encompassing 1/6th of the whole 
planet, provided significant finance to all larger (especially for towns) construction projects. Moreover, in the 1940s, private property had been abolished, resulting in complete state ownership of the land. In addition, the war had left largely demolished areas that turned out to be practical playgrounds for architects in Tallinn, Pärnu, Narva and elsewhere in Estonia.

Though suffering irrational demolitions (Narva, Pärnu), after World War II, Estonian towns gained axially arranged representative, sometimes oversized, but perspectively balanced and functional plans (Sillamäe, Kohtla-Järve).

\section{References}

Armani, H. (1946) Linnadeplaneerimise küsimusi ENSV-s. (Problems Concerning Town Planning in Estonian SSR). ENSV Arhitektidealmanahh. pp. 5-8. (in Estonian)

Armani, H. (1948) Detailplaneerimise küsimusi. (Problems Concerning Detailed Planning.) ENSV Arhitektide. Almanahh 1947, pp. 10-17. (in Estonian)

Bölau, K. (1937) Tallinna Vabadusväljaku ruumilisekujundamiseprojektide võistlus (Content of Projects Concerning Spatial Design of Liberty Square of Tallinn.) Tehnika Ajakiri. 4, pp. 86-87.

Bunin, A. V. (1945) Gradostroitel'stvo (Town Planning.) Izdatel'stvo Akademii Arhitektury SSSR. Moscow. 1945. (in Russian)

Capenko, M. R. (1952) O realicticheskih osnovah Covetskoj arhitektury (About Realistic Principles of Soviet Architecture.) Moscow. Gosudarstvennoe izdatel'stvo literature y postroitel'stvui arhitekture. (in Russian)

Ederberg, E. (1948) Narva vanalinna ülesehitamise probleeme. (Problems Concerning Restoration of Old Town of Narva.) ENSV Arhitektide Almanahh 1947. pp. 60-65. (in Estonian)

Gorich, I. (1946) V masterskojzodchego. (In Architect's Atelier.) Sovetskaja Estonija, August 10th, 1946. (in Russian)

Groys, B. (1998) Stalin-stiil. (Stalin-style.) Akadeemia. 3, pp. 636-670. (in Estonian)

Groys, B. (1998) Stalin-stiil. (Stalin-style.) Akadeemia. 4, pp. 855-891. (in Estonian)

Härmson, P. (1983) Pärnu keskuse planeerimiskavakujunemine. (Development of Planning Project of Pärnu Centre.) Ehitus ja Arhitektuur. 3, pp. 31-43. (in Estonian)

Hronika. XIV plenum Pravlenija Sojuzasovetskiharhitektrov (Chronicle. XIV Plenum of the Union of Soviet Architects). Arhitektura SSSR. 7, pp. 3133. 1952. (in Russian)

Kodres, K. (2008). Sovietization of classical architecture: the case of Estonia. In: Quo vadis architectura: Architectural tendencies in the late 1930s, 1940s, and the early 1950s, pp. 130-151. Helsinki. University of Technology. 2008.

Kosenkova, J. (2009). Sovetskij gorod 1940-h-pervoj poloviny 1950-h godov. Ot tvorcheskih poiskov k praktike stroitel'stva. (Soviet Town from 1940s to the First Half of 1950s. From the Creative Searches to the Practice of Building. Knizhnyj dom "LIBROKOM". Moscow. 2009. (in Russian)

Kratkij spravochnik arhitektora (Short Regulations for Architect.) Moscow: Gosudarstvennoe izdatel'stvo literatury po stroitel'stvu i arhitekture, 1952. (in Russian)

Kruft, H-W. (1994) A History of Architectural Theory: from Vitruvius to the Present. Princeton Architectural Press, New York. 1994.

Malinina, T. A. (1978) Iz istorii sovetskoj arhitektury 1941-1945 gg. Dokumenty $i$ materialy. Hronika voennyh let. Arhitekturnaja pechat. (From History of Soviet Architecture 1941-1945. Chronicle of war years. Architectural Publishing.) Moscow. Izdatel'stvo "Nauka". 1978. (in Russian)
Meigas, V. (1948) Eesti NSV arhitektide loomingulised ülesanded. (Creative Tasks of the Architects of Estonian SSR.) ENSV Arhitektide Almanahh. pp. 5-9. 1947. (in Estonian)

Ob ustranenii izlishestv $\mathrm{v}$ proektirovanii i stroitel'stve. Postanovlenie Central'nogo Komiteta KPSS i Soveta Ministrov SSSR 4 nojabrja 1955 goda (About Abandonment of Exaggerations in Planning and Building. Resolution of the Central Committee of the CPSU and the Council of Ministries of USSR in 4th November 1955.) Gospolitizdat, Moscow. 1955. (in Russian)

Parek, E. (1971) Pärnu sajandeis. Ehituskunstiline ülevaade (Pärnu Thoroughout Centuries, Architectural Review.) Eesti Raamat. Tallinn. 1971. (in Estonian)

Plenum pravlenija Sojuza arhitektrov (Plenum of the Board of the Union of Soviet Architects.) 1943. Pravda, August 19 ${ }^{\text {th }}$. (in Russian)

Shumovskij, G. (1953) Budushhee goroda-kurorta. (Future of Town-resort.) Sovetskaja Estonija, January $14^{\text {th }}$. (in Russian)

Sovetskaja arhitektura za XXX let RSFSR (Soviet Architecture within XXX years of RSFSR.) Moscow: Izdatel'stvo Akademii Arhitektury SSSR, 1950. (in Russian)

Tvorcheskie zadachi sovetskih arhitektorov v pjatiletnem plane vosstanovlenija i razvitija narodnogo hozjajstva. Materialy XII plenuma Sojuza sovetskih arhitektorov SSSR. (Creative Tasks for Soviet Architects within the Five Year Plan of Restoration and Development of Peoples' Economy. Materials of the XII Plenum of the Union of Soviet Architects of USSR.), Moscow: Gosudarstvennoe izdatel'stvo arhitektury i gradostroitel'stva, 1948. (in Russian)

Tvorcheskie zadachi sovetskih arhitektorov v pjatiletnem plane vosstanovlenija i razvitija narodnogo hozjajstva. Materialy XIII plenuma Sojuza sovetskih arhitektorov SSSR (Creative Tasks for Soviet Architects within the Five Year Plan of Restoration and Development of Peoples' Economy. Materials of the XIII Plenum of the Union of Soviet Architects of USSR). Moscow: Gosudarstvennoe izdatel'stvo arhitektury i gradostroitel'stva, 1951. (in Russian)

Vabadussõja üleriikliku mälestusmonumendi püstitamise seadus (Law Concerning Erection of Monument of the War of Independence). Riigi Teataja, no. 47, art. 371. (1936). (in Estonian)

Volkov, L. (1991) Eesti Arhitektuurist aastail 1940-1954 (About Estonian Architecture within 1940-1954.) In Linnaehitus ja Arhitektuur, Tallinn, 183-213. Tallinn: Ehituse Teadusliku Uurimise Instituut. (in Estonian)

Zholtovskij, I. V. (1940). Ancambl' v arhitekture (Ensemble in Architecture.) Stroitel'naja gazeta, May $30^{\text {th }}$. (in Russian)

Eesti Riigiarhiiv $($ ERA $)=$ Estonian State Archives. fond 2211 Trükikäitis "Postimees" (Printshop "Postimees"). fond 3799 Pärnu Linnavalitsus (Municipality of Pärnu). fond R-1992 Eesti NSV Ministrite Nõukogu juures asuv Riiklik Ehituskomitee [Stately Committee of Reconstruction located at the Council of Ministries of Estonian SSR].

Eesti Ajalooarhiiv $($ EAA $)=$ Estonian Historical Archives. fond 2100 Eesti Vabariigi Tartu Ülikool (University of Tartu of the Republic of Estonia).

Eesti Arhitektuurimuuseum (EAM) $=$ Museum of Estonian Architecture fond 3 1940.-1950. aastate arhitektuur (Architecture of 1940s-1950s) 